\title{
Thermosporothrix hazakensis gen. nov., sp. nov., isolated from compost, description of Thermosporotrichaceae fam. nov. within the class Ktedonobacteria Cavaletti et al. 2007 and emended description of the class Ktedonobacteria
}

Correspondence

Shuhei Yabe

kennan-6@kennan-e.co.jp

\author{
Shuhei Yabe, ${ }^{1}$ Yoshifumi Aiba, ${ }^{2,3}$ Yasuteru Sakai, ${ }^{1}$ Masaru Hazaka ${ }^{1}$ \\ and Akira Yokota ${ }^{2}$
}

\begin{abstract}
${ }^{1}$ Hazaka Plant Research Center, Kennan Eisei Kogyo Co., Ltd, 44 Aza-Inariyama, Oaza-Ashitate, Murata-cho, Shibata-gun, Miyagi 989-1311, Japan

${ }^{2}$ Institute of Molecular and Cellular Biosciences, The University of Tokyo, 1-1-1 Yayoi Bunkyo-ku, Tokyo 113-0032, Japan

${ }^{3}$ F.T. Innovation, 6F Royal Ikebukuro Bldg, 39-9, Nishi-Ikebukuro 2-chome Toshima-ku, Tokyo 171 0021, Japan
\end{abstract}

The phylum Chloroflexi is currently divided phylogenetically into at least five classes, Chloroflexi (Garrity \& Holt, 2001), Caldilineae (Yamada et al., 2006), Thermomicrobia (Hugenholtz \& Stackebrandt, 2004), Anaerolineae (Yamada et al., 2006) and 'Dehalococcoidetes' (Hugenholtz \& Stackebrandt, 2004). It also contains a clone cluster of uncultured bacteria (Morris et al., 2004). The class

The GenBank/EMBL/DDBJ accession numbers for the $16 \mathrm{~S}$ rRNA gene sequences of strain SK20-1 ${ }^{\top}$ and Ktedonobacter racemifer DSM $44963^{\top}$ are AB500145 and AB510917.

A photograph of a colony of strain SK20-1 $1^{\top}$ and a global $16 \mathrm{~S}$ rRNA gene sequence-based neighbour-joining tree are available as supplementary material with the online version of this paper.
Ktedonobacteria, which contains one cultured species with a validly published name, Ktedonobacter racemifer, has not yet been assigned to a phylum. However, the highest levels of binary similarity of $16 \mathrm{~S}$ rRNA gene sequences were with representatives of the phylum Chloroflexi (Cavaletti et al., 2006). The association between $K$. racemifer SOSP $1-21^{\mathrm{T}}$ and species in the phylum Chloroflexi was not supported by high bootstrap values in the phylogenetic tree, and there are several differences in morphology and chemotaxonomy between the two. Therefore, Cavaletti et al. (2006) reported that $K$. racemifer SOSP $1-21^{\mathrm{T}}$ may belong to a new phylum. However, they did not propose a new phylum, since the phylum Chloroflexi is highly heterogeneous with respect to phylogenetic, morphological and physiological characteristics. 
In this study, we report the cultivation and isolation of a novel thermophilic and branched mycelium-forming bacterium from compost belonging to the class Ktedonobacteria. We formally propose to amend the description of the class Ktedonobacteria as suggested by Cavaletti et al. (2006), by placing it in the phylum Chloroflexi.

The sample was obtained from ripe compost produced by a field-scale composter (Hazaka system; Hazaka Plant Kogyo Co., Ltd), which had been used for the treatment of livestock excreta. The composter is an open strip furrow ( $100 \mathrm{~m}$ long by $3 \mathrm{~m}$ wide by $2 \mathrm{~m}$ deep) with an automatic scoop-type turner. The details of this system were described previously (Yabe et al., 2009). The sample was collected in a plastic bag (Ziploc), transported to the laboratory and stored at room temperature until use.

The isolation medium contained (per litre distilled water) $1 \mathrm{~g}$ yeast extract, $2 \mathrm{~g}$ tryptone, $1 \mathrm{~g} \mathrm{NaCl}, 1 \mathrm{~g}$ $\mathrm{MgSO}_{4} \cdot 7 \mathrm{H}_{2} \mathrm{O}, 5 \mathrm{~g}$ compost powder (described below) and $20 \mathrm{~g}$ agar. The medium was supplemented with $20 \mathrm{mg}$ trimethoprim, $10 \mathrm{mg}$ nalidixic acid and $20 \mathrm{mg}$ kanamycin $1^{-1}$. The compost powder was prepared by grinding the compost to a fine powder in a mortar after drying at $60{ }^{\circ} \mathrm{C}$ overnight. The $\mathrm{pH}$ of the isolation plates was adjusted to 7.0 with $\mathrm{NaOH}$ at room temperature. The sample ( $1 \mathrm{~g}$ wet weight) was serially diluted in saline solution, and aliquots of the dilutions were plated on the plates. The plates were incubated at $50{ }^{\circ} \mathrm{C}$ for 7 days. One of the colonies that formed aerial mycelium was picked, grown and purified by plating three times. The colony was restreaked, and a stock culture was prepared by inoculating agar slants from the second plate. The isolate was designated strain SK20-1 ${ }^{\mathrm{T}}$.

Morphology of cells grown at $50{ }^{\circ} \mathrm{C}$ for 7 days on ISP3 agar (Shirling \& Gottlieb, 1966) was examined with a phasecontrast microscope. For scanning electron microscopy (JSM6700F; JEOL Inc.), a suitable agar block including a colony grown at $50{ }^{\circ} \mathrm{C}$ for 14 days on ISP3 agar was cut out with a scalpel, mounted on a glass slide, fixed for $24 \mathrm{~h}$ in a sealed bin containing $2 \%$ osmium tetroxide and freezedried for $4 \mathrm{~h}$. The dried sample was mounted on a specimen support with carbon tape, covered with gold film by sputter coating under a vacuum and observed in highvacuum mode at $3 \mathrm{kV}$. For transmission electron microscopy (TEM), a suitable agar block including a colony grown at $50{ }^{\circ} \mathrm{C}$ for 5 days on ISP3 agar was fixed overnight by steeping with $2 \%$ glutaraldehyde buffered with $0.1 \mathrm{M}$ sodium cacodylate. After washing with the same buffer, the block was post-fixed for $90 \mathrm{~min}$ with $1 \%$ permanganic acid potassium salt and washed with distilled water. TEM preparations were carried out at $4{ }^{\circ} \mathrm{C}$. The block was then dehydrated in an acetone series at room temperature and embedded in Spurr resin at $60{ }^{\circ} \mathrm{C}$ for $24 \mathrm{~h}$. It was cut by ultramicrotome into $80-90 \mathrm{~nm}$ slices, triple-stained with tannic acid, uranyl acetate and lead citrate and observed and photographed on a JEOL JEM1200EX at an acceleration voltage of $80 \mathrm{kV}$.
Colonies of SK20-1 ${ }^{\mathrm{T}}$ were $3-5 \mathrm{~cm}$ in diameter after incubation for 7 days at $50{ }^{\circ} \mathrm{C}$ on ISP3 agar (see Supplementary Fig. S1, available in IJSEM Online). Strain SK20-1 ${ }^{\mathrm{T}}$ formed vegetative and thick aerial mycelia on solid medium; both were irregularly branched and similar in morphology to actinomycetes (Fig. 1a, b). Spores, 1.0$2.0 \mu \mathrm{m}$ long and $0.7-1.0 \mu \mathrm{m}$ wide, were borne in a cluster and had a fig-like shape (Fig. 1c). The spores exhibited refractivity under a phase-contrast microscope (Fig. 1b). As shown in Fig. 1(d), the spore cells were covered with a double membrane and surrounded by thick cell walls, with the cells being clearly separated from the mycelium by membranes and walls.

To test for heat resistance of the spores, colonies of strain SK20- $1^{\mathrm{T}}$ were incubated at $50{ }^{\circ} \mathrm{C}$ for 7 days on ISP3 agar, suspended in $0.5 \% \mathrm{NaCl}(1 \mathrm{ml})$ and heated at 60,70 or $80{ }^{\circ} \mathrm{C}$ in a water bath for 10 or $20 \mathrm{~min}$. After heat treatment, $0.1 \mathrm{ml}$ of the treated sample was added to $100 \mathrm{ml}$ ISP1 medium and incubated at $50{ }^{\circ} \mathrm{C}$ for 2 weeks. After heating at 60 or $70{ }^{\circ} \mathrm{C}$ for $20 \mathrm{~min}$, spores grew after 2 days; those heated at $80{ }^{\circ} \mathrm{C}$ for 10 min grew after 5 days, while those heated at $80{ }^{\circ} \mathrm{C}$ for 20 min showed no growth. Thus, spores of strain SK20-1 ${ }^{\mathrm{T}}$ are sensitive to heat.

The dipicolinic acid content of spores of strain SK20-1 ${ }^{\mathrm{T}}$ was determined by the method of Janssen et al. (1958). Bacillus cereus NBRC 3836 and Thermobifida fusca NBRC $14071^{\mathrm{T}}$ were similarly tested and used as positive and negative controls, respectively. Spores of strain SK20-1 ${ }^{\mathrm{T}}$ and Thermobifida fusca NBRC $14071^{\mathrm{T}}$ were raked with a sterilized toothpick from well-sporulated colonies, incubated at $50{ }^{\circ} \mathrm{C}$ for 7 days on ISP3 agar and suspended in $0.5 \% \mathrm{NaCl}(1 \mathrm{ml})$. Preparation of spore suspensions of Bacillus cereus NBRC 3836 was performed according to the method of Bhothipaksa \& Busta (1978). The wet weight of each spore sample was about $50 \mathrm{mg}$. Dipicolinic acid was detected in spores of Bacillus cereus NBRC 3836 but not in those of strain SK20 $-1^{\mathrm{T}}$ or Thermobifida fusca NBRC $14071^{\mathrm{T}}$.

In order to determine the effect of $\mathrm{pH}$, temperature and $\mathrm{NaCl}$ on growth, strain SK20-1 ${ }^{\mathrm{T}}$ was cultivated in ISP3 medium. Temperature, $\mathrm{pH}$ and $\mathrm{NaCl}$ concentration tests were carried out at $20-60{ }^{\circ} \mathrm{C}(\mathrm{pH} 7.0), \mathrm{pH} 4.5-10.5$ $\left(50{ }^{\circ} \mathrm{C}\right)$ and $0-3 \% \mathrm{NaCl}\left(50{ }^{\circ} \mathrm{C}, \mathrm{pH} 7.0\right)$. The $\mathrm{pH}$ was adjusted with $\mathrm{HCl}$ or $\mathrm{NaOH}$ at room temperature. Anaerobic growth was observed in test tubes by adding $0.1 \%$ (w/v) $\mathrm{NaNO}_{3}, \mathrm{Na}_{2} \mathrm{SO}_{3}, \mathrm{NaNO}_{2}$ or $\mathrm{Na}_{2} \mathrm{~S}_{2} \mathrm{O}_{3}$ to ISP1 medium (Shirling \& Gottlieb, 1966). Air was replaced with $\mathrm{N}_{2}$. Assimilation of various sole carbon sources (at $1 \%$; Larabinose, D-xylose, D-glucose, D-fructose, sucrose, Lrhamnose, raffinose, inositol and mannitol) was assessed using Pridham-Gottlieb agar (Shirling \& Gottlieb, 1966) and determined to be positive or negative by the method of Shirling \& Gottlieb (1966). Hydrolysis of cellulose, xylan, chitin, starch, gelatin and casein was evaluated on isolation plates supplemented with each substrate at a concentration of $1 \%(\mathrm{w} / \mathrm{v})$. The presence of a clear zone 

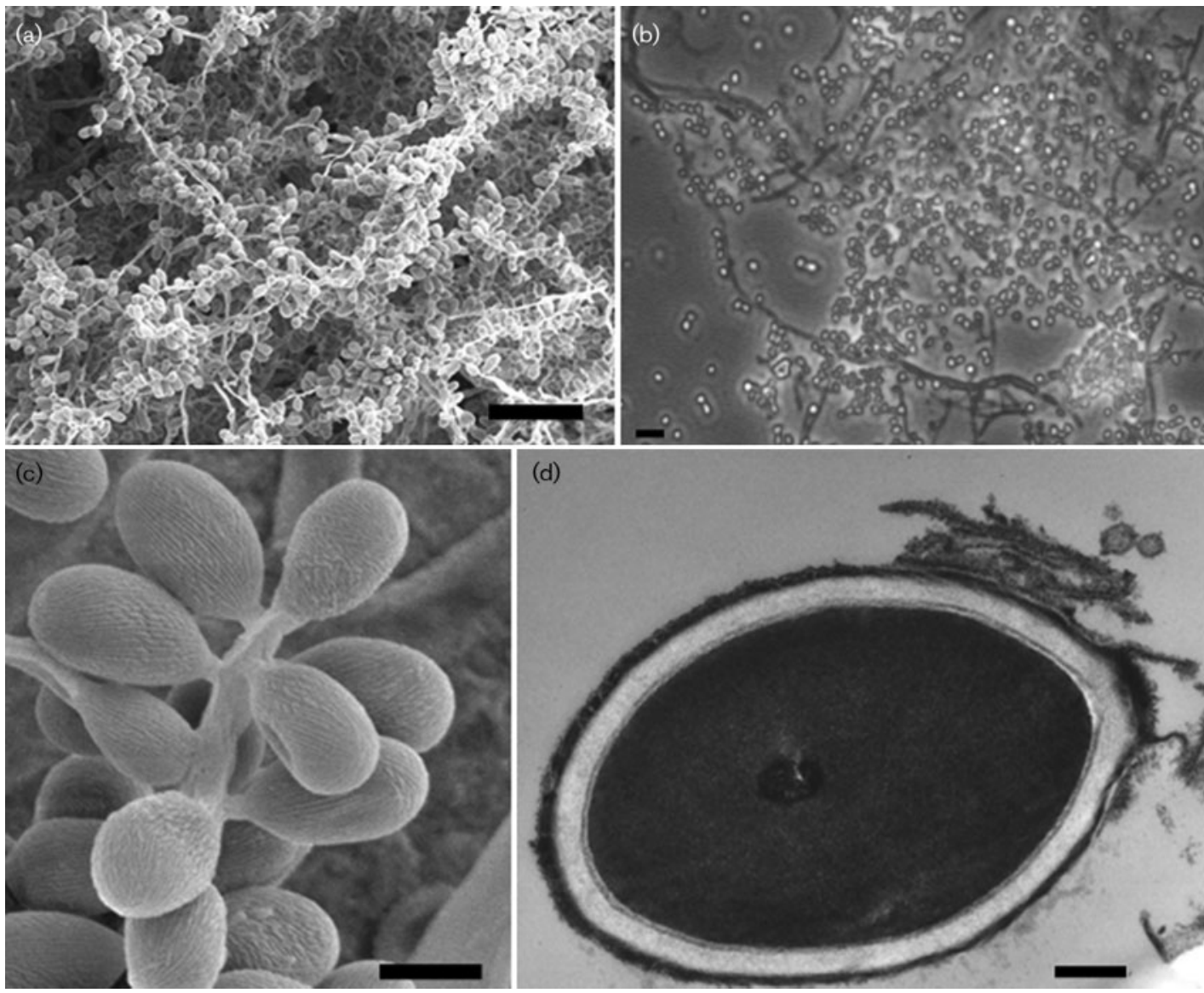

Fig. 1. Photomicrographs of cells of strain SK20-1 ${ }^{\top}$. (a, c) Scanning electron micrographs of strain SK20-1 $1^{\top}$. Bars, $10 \mu \mathrm{m}(\mathrm{a})$ and $1 \mu \mathrm{m}$ (c). (b) Phase-contrast photomicrograph of cells of strain SK20-1 $1^{\top}$ grown on ISP3 agar at $50{ }^{\circ} \mathrm{C}$ for 7 days. Bar, $10 \mu \mathrm{m}$. (d) Transmission electron micrograph of an ultrathin-sectioned spore of strain SK20-1 ${ }^{\top}$. Bar, $200 \mathrm{~nm}$.

around the colony indicated that there was hydrolysis. Catalase activity was determined by bubble production in a $3 \%$ hydrogen peroxide solution. Gram staining was carried out with the modified Hucker method (Smibert \& Krieg, 1994).

Differential phenotypic characteristics between strain SK20- $1^{\mathrm{T}}$ and K. racemifer SOSP $1-21^{\mathrm{T}}$ are summarized in Table 1. Strain SK20-1 ${ }^{\mathrm{T}}$ is Gram-stain-positive. It grows at $31-58{ }^{\circ} \mathrm{C}$, with optimum growth at $50{ }^{\circ} \mathrm{C}$; there was no growth below 28 or above $60{ }^{\circ} \mathrm{C}$. Strain SK20-1 ${ }^{\mathrm{T}}$ is able to grow at $\mathrm{pH}$ 5.4-8.7, with optimum growth at $\mathrm{pH} 7.0$; no growth was observed below $\mathrm{pH} 5.0$ or above $\mathrm{pH}$ 9.1. It does not require $\mathrm{NaCl}$ for growth, but growth is inhibited by $\mathrm{NaCl}$ at concentrations higher than $2 \%$. It grows only under aerobic conditions. Strain SK20-1 ${ }^{\mathrm{T}}$ utilizes D-xylose, D-glucose, sucrose, L-rhamnose, inositol and mannitol as sole carbon sources and hydrolyses cellulose, xylan, chitin and casein but not starch. It is catalase-positive and does not produce $\mathrm{H}_{2} \mathrm{~S}$.

Cellular fatty acids of strain SK20-1 ${ }^{\mathrm{T}}$ were prepared from cell mass grown on ISP1 medium for 4 days at $50{ }^{\circ} \mathrm{C}$ and then separated and identified with the Microbial Identification Systems (MIDI Inc.). Cell walls were prepared by the methods described by Schleifer \& Kandler (1972) and amino acids in the cell-wall hydrolysate were identified by TLC (Harper \& Davis, 1979) and HPLC, as their phenylthiocarbamoyl derivatives, with an HPLC apparatus (LC-10AD; Shimadzu) equipped with a Wakopak WS-PTC column (Wako Pure Chemical Industries) as described by Yokota et al. (1993). Cell-wall sugars were determined as alditol acetate derivatives by GLC using a Shimadzu GC-17A apparatus equipped with an Rtx 2330 $(0.32 \mathrm{~mm} \times 30 \mathrm{~m})$ column. Phospholipids were extracted and identified using two-dimensional TLC, followed by spraying with appropriate detection reagents, according to the method of Tindall (1990a, b). Genomic DNA of the isolate was prepared using a method modified from Marmur (1961), in which achromopeptidase and lysozyme (final concentrations 0.5 and $0.75 \mathrm{mg} \mathrm{ml}^{-1}$, respectively) were used for cell lysis. RNA was digested with RNase mix solution $\left(50 \mu \mathrm{ml}^{-1}\right)$ (Wako). The $\mathrm{G}+\mathrm{C}$ content of the genomic DNA was determined by HPLC (Tamaoka \& Komagata, 1984) using a COSMOSIL 5 $\mathrm{C}_{18}$-AR-II packed 
Table 1. Differential characteristics of strain $\mathrm{SK} 20-1^{\top}$ and Ktedonobacter racemifer SOSP1-2 $1^{\top}$

Data for $K$. racemifer SOSP1-21 ${ }^{\mathrm{T}}$ were taken from Cavaletti et al. (2006). Both strains stain Gram-positive, have MK-9 $\left(\mathrm{H}_{2}\right)$ as the major quinone and are positive for catalase, growth with $1 \% \mathrm{NaCl}$ and hydrolysis of casein. Both strains are negative for growth with $3 \%$ $\mathrm{NaCl}$. ND, No data available.

\begin{tabular}{|c|c|c|}
\hline Characteristic & $\begin{array}{c}\text { Strain } \\
\text { SK20-1 }\end{array}$ & $\begin{array}{l}\text { K. racemifer } \\
\text { SOSP1-21 }\end{array}$ \\
\hline Spore size $(\mu \mathrm{m})$ & $1.0-2.0 \times 0.7-1.0$ & $1.6-1.8$ \\
\hline DNA G $+C$ content $(\mathrm{mol} \%)$ & 54.0 & 53.9 \\
\hline Gelatin liquefaction & - & + \\
\hline Production of $\mathrm{H}_{2} \mathrm{~S}$ & - & + \\
\hline $\begin{array}{l}\text { Growth in the presence of } 2 \% \\
\mathrm{NaCl}\end{array}$ & - & ND \\
\hline \multicolumn{3}{|l|}{ Temperature for growth $\left({ }^{\circ} \mathrm{C}\right)$} \\
\hline Range & $31-58$ & $17-40$ \\
\hline Optimum & 50 & $28-33$ \\
\hline \multicolumn{3}{|l|}{$\mathrm{pH}$ for growth } \\
\hline Range & $5.4-8.7$ & $4.2-7.2$ \\
\hline Optimum & 7.0 & 6.0 \\
\hline \multicolumn{3}{|l|}{ Hydrolysis of: } \\
\hline Starch & - & + \\
\hline Cellulose & + & - \\
\hline Xylan & + & - \\
\hline Chitin & + & - \\
\hline \multicolumn{3}{|l|}{ Utilization of: } \\
\hline L-Arabinose & - & $\mathrm{ND}$ \\
\hline $\begin{array}{l}\text { D-Xylose, D-glucose, D- } \\
\text { fructose, sucrose, L-rhamnose, } \\
\text { raffinose, inositol, mannitol }\end{array}$ & + & $\mathrm{ND}$ \\
\hline Major cellular fatty acid(s) & iso- $\mathrm{C}_{17: 0}$ & $\begin{array}{c}\mathrm{C}_{16: 1} 2-\mathrm{OH}, \\
\text { iso- } \mathrm{C}_{17: 0}\end{array}$ \\
\hline Cell-wall amino acids ${ }^{*}$ & $\begin{array}{l}\text { Glu, Ser, } \\
\text { Ala, Orn }\end{array}$ & $\begin{array}{l}\text { Glu, Gly, } \\
\text { Ala, Ser, } \\
\text { Orn }\end{array}$ \\
\hline Cell-wall sugars* & Rha, Man & Ara, Gal \\
\hline Polar lipids ${ }^{\star}$ & $\begin{array}{l}\text { PI, PIM, } \\
\text { PG, DPG }\end{array}$ & PI, PG, DPG \\
\hline
\end{tabular}

*Orn, Ornithine; Ara, arabinose; Gal, galactose; Man, mannose; Rha, rhamnose; DPG, diphosphatidylglycerol; PG, phosphatidylglycerol; PI, phosphatidylinositol; PIM, phosphatidylinositol mannosides.

column $(4.6 \mathrm{~mm} \times 250 \mathrm{~mm})$ (Nacalai Tesque) with a DNA-GC kit (Yamasa Shouyu).

The $\mathrm{G}+\mathrm{C}$ content of strain $\mathrm{SK} 20-\mathrm{1}^{\mathrm{T}}$ was $54.0 \mathrm{~mol} \%$, as determined by HPLC analysis (Table 1 ). The predominant menaquinone $(85 \%)$ was MK-9 $\left(\mathrm{H}_{2}\right)$; MK-9 $\left(\mathrm{H}_{4}\right)$ was present as a minor component $(5 \%)$. The major fatty acid was iso- $\mathrm{C}_{17: 0}(52.8 \%)$. The composition of cellular fatty acids is shown in Table 2 . The polar lipids consisted of phosphatidylinositol, phosphatidylinositol mannosides, phosphatidylglycerol, diphosphatidylglycerol and an unknown glycolipid (Table 1). The peptidoglycan contained
Table 2. Cellular fatty acid compositions of strain SK20-1 ${ }^{\top}$ and $K$. racemifer SOSP $1-21^{\top}$

Data for K. racemifer SOSP $1-21^{\mathrm{T}}$ were taken from Cavaletti et al. (2006). Values are percentages of total fatty acids; fatty acids present at less than $1 \%$ in both strains are not shown. ND, Not detected/not reported.

\begin{tabular}{|lcc|}
\hline Fatty acid & Strain SK20-1 $^{\mathbf{T}}$ & K. racemifer $_{\text {SOSP1-21 }}{ }^{\mathbf{T}}$ \\
\hline iso- $\mathrm{C}_{15: 0}$ & 0.64 & 2.37 \\
$\mathrm{C}_{16: 0}$ & 10.03 & 6.66 \\
iso- $_{16: 0}$ & 1.14 & 11.54 \\
$10-\mathrm{Methyl} \mathrm{C}_{16: 0}$ & 1.26 & 7.79 \\
$\mathrm{C}_{16: 1}$-OH & 9.39 & 29.65 \\
$\mathrm{C}_{17: 0}$ & 1.76 & $\mathrm{ND}$ \\
iso- $_{17: 0}$ & 52.79 & 25.00 \\
anteiso-C & 10.30 & 9.61 \\
$\mathrm{C}_{18: 0}$ & 7.28 & 2.01 \\
$\mathrm{C}_{18: 1} \omega 9 c$ & 0.71 & 1.21 \\
\hline
\end{tabular}

glutamic acid, serine, alanine and ornithine in a molar ratio of $1.00: 1.07: 2.64: 0.83$. Cell-wall sugars of strain SK20-1 ${ }^{\mathrm{T}}$ were rhamnose and mannose. Differential chemotaxonomic characteristics of strain SK20-1 ${ }^{\mathrm{T}}$ and $K$. racemifer SOSP $1-21^{\mathrm{T}}$ are summarized in Table 1 .

The 16S rRNA gene of $K$. racemifer DSM $44963^{\mathrm{T}}$ was sequenced because the sequence reported previously for strain SOSP $1-21^{\mathrm{T}}$ was short (GenBank accession no. AM180156; $1386 \mathrm{bp})$. The 16S rRNA genes of strain SK20-1 $1^{\mathrm{T}}$ and $K$. racemifer DSM $44963^{\mathrm{T}}$ were amplified with primers F27 (5'-AGAGTTTGATCATGGCTCGA-3'; positions 8-27 of the Escherichia coli 16S rRNA gene) and R1492 (5'-GGCTACCTTGTTACGACTT-3'; 1510-1492). PCR thermal cycling was carried out in a TaKaRa PCR Thermal Cycler MP-3000 (TaKaRa Bio) using the following parameters: $94{ }^{\circ} \mathrm{C}$ for 2 min followed by 30 cycles at $94{ }^{\circ} \mathrm{C}$ for $1 \mathrm{~min}, 52{ }^{\circ} \mathrm{C}$ for $1 \mathrm{~min}$ and $72{ }^{\circ} \mathrm{C}$ for $1 \mathrm{~min}$ with a final extension cycle of $72^{\circ} \mathrm{C}$ for 2 min. Purified PCR products were sequenced as described by Lin et al. (2004).

To construct a global phylogenetic tree, the 16S rRNA gene sequence of strain SK20-1 ${ }^{\mathrm{T}}$ was automatically aligned using the ARB program (http://www.arb-home.de/) to a set of 7006 pre-aligned 16S rRNA gene sequences of type strains in the Bacteria available from the All-Species Living Tree Project (LTP) dataset based on SILVA release _s95 (ARB format, 17 October 2008; Yarza et al., 2008). After manual refinement of the alignment, the sequence of strain SK20$1^{\mathrm{T}}$ was added to the reference tree provided with the LTP_s95 database using quick parsimony. Reference tree construction had been performed by using the maximumlikelihood algorithm RaxML (Stamatakis, 2006) in LTP (Yarza et al., 2008). Representatives of several phyla or close relatives of strain SK20-1 ${ }^{\mathrm{T}}$ were chosen, and detailed phylogenetic trees were reconstructed by the following methods (Figs 2 and 3). The 16S rRNA gene sequence of strain $\mathrm{SK} 20-1^{\mathrm{T}}$ was compared with sequences obtained 




Fig. 2. Neighbour-joining tree based on 1191 aligned positions of the 16S rRNA gene showing the position of strain SK20-1 ${ }^{\top}$ and K. racemifer DSM $44963^{\top}$ among members of other phyla. The sequences of Aquifex pyrophilus $\mathrm{Kol}^{\mathrm{T}} \mathrm{a}^{\top}$ (GenBank accession no. M83548) and Thermotoga maritima $\mathrm{MSB}^{\top}$ (accession no. M21774) were used as an outgroup (not shown). Numbers at nodes are bootstrap percentages based on 1000 replicated datasets; only values greater than $50 \%$ are shown. Bar, $2 \%$ sequence dissimilarity. DDBJ/EMBL/GenBank accession numbers for reference strains are shown in parentheses.

from GenBank. Multiple alignments of the sequences were performed using CLUSTAL W (version 1.83) (Thompson et al., 1994), and gaps and unidentified base positions were edited using BioEdit (Hall, 1999). A phylogenetic tree was constructed with the maximum-likelihood method (Felsenstein, 1981) using PhyML (Guindon \& Gascuel, 2003), the neighbour-joining method (Saitou \& Nei, 1987) and the maximum-parsimony method (Fitch, 1971) using MEGA version 4.1 (Tamura et al., 2007), with bootstrap values based on 100, 1000 and 1000 replications, respectively (Felsenstein, 1985). Evolutionary distances were computed using Kimura's two-parameter method (Kimura, 1980).

The closest relative of strain SK20-1 ${ }^{\mathrm{T}}$ with a validly published name is K. racemifer DSM $44963^{\mathrm{T}}$, with $88.5 \%$ sequence similarity. All other cultured species of the phylum Chloroflexi with validly published names are related more distantly, showing $16 \mathrm{~S}$ rRNA gene sequence similarities of less than $81 \%$ (Caldilinea aerophila, $81 \%$; Sphaerobacter thermophilus, 81\%; Anaerolinea thermolimosa, 79\%). The uncultured bacterial clone B424, detected from Hawaiian volcanic deposits and belonging to the same cluster as strain SK20-1 $1^{\mathrm{T}}$, has $16 \mathrm{~S}$ rRNA gene sequence similarity of $87 \%$ with strain SK20-1 $1^{\mathrm{T}}$. Hawaiian volcanic bacterial clones are also present in clusters 1 and 3 (see Fig. 3). The sequence similarities of strain SK20-1 ${ }^{\mathrm{T}}$ with clusters $1,2,3$ and GS were $85-88,87-88,85-87$ and $84-85 \%$, respectively. Phylogenetic trees based on 16S rRNA gene sequences (Fig. 2 and Supplementary Fig. S2) indicate that strain
SK20-1 $1^{\mathrm{T}}$ and K. racemifer DSM $44963^{\mathrm{T}}$ belong to the phylum Chloroflexi, because the Chloroflexi cluster, including strain SK20-1 ${ }^{\mathrm{T}}$ and K. racemifer DSM $44963^{\mathrm{T}}$, was formed at a high bootstrap value of $89 \%$; the global phylogenetic tree (Supplementary Fig. S2) includes 7007 type strain sequences from the Bacteria, indicating that strain $\mathrm{SK} 20-1^{\mathrm{T}}$ and $K$. racemifer SOSP1-2 ${ }^{\mathrm{T}}$ were placed in the cluster Chloroflexi. As shown in Fig. 3, the bootstrap value for the node of the class Ktedonobacteria is $100 \%$ according to the maximumlikelihood, neighbour-joining and maximum-parsimony methods, suggesting that strain SK20-1 ${ }^{\mathrm{T}}$ belongs to the class Ktedonobacteria. The cluster Ktedonobacteria is subdivided into two major clusters (Ktedonobacterales and GS); therefore, the class Ktedonobacteria has two major orders, and strain SK20-1 ${ }^{\mathrm{T}}$ belongs to the order Ktedonobacterales. The GS cluster consists of four cultivated strains isolated from geothermal soils in New Zealand (Stott et al., 2008), but no names have been validly published for these strains. These strains also form spores. The cluster Ktedonobacterales is subdivided into four subclusters (Thermosporotrichaceae fam. nov. and clusters 1-3); therefore, the order Ktedonobacterales has at least four lineages at the family level. Furthermore, strain SK20-1 ${ }^{\mathrm{T}}$ shows only $87-88 \% 16 \mathrm{~S}$ rRNA gene sequence similarity with members of cluster 2 , including K. racemifer DSM $44963^{\mathrm{T}}$. These facts suggest that strain SK20- $1^{\mathrm{T}}$ and K. racemifer DSM $44963^{\mathrm{T}}$ should be separated at the family level.

In addition, physiological and chemotaxonomic characteristics clearly differentiate strain $\mathrm{SK} 20-\mathrm{1}^{\mathrm{T}}$ from the most 

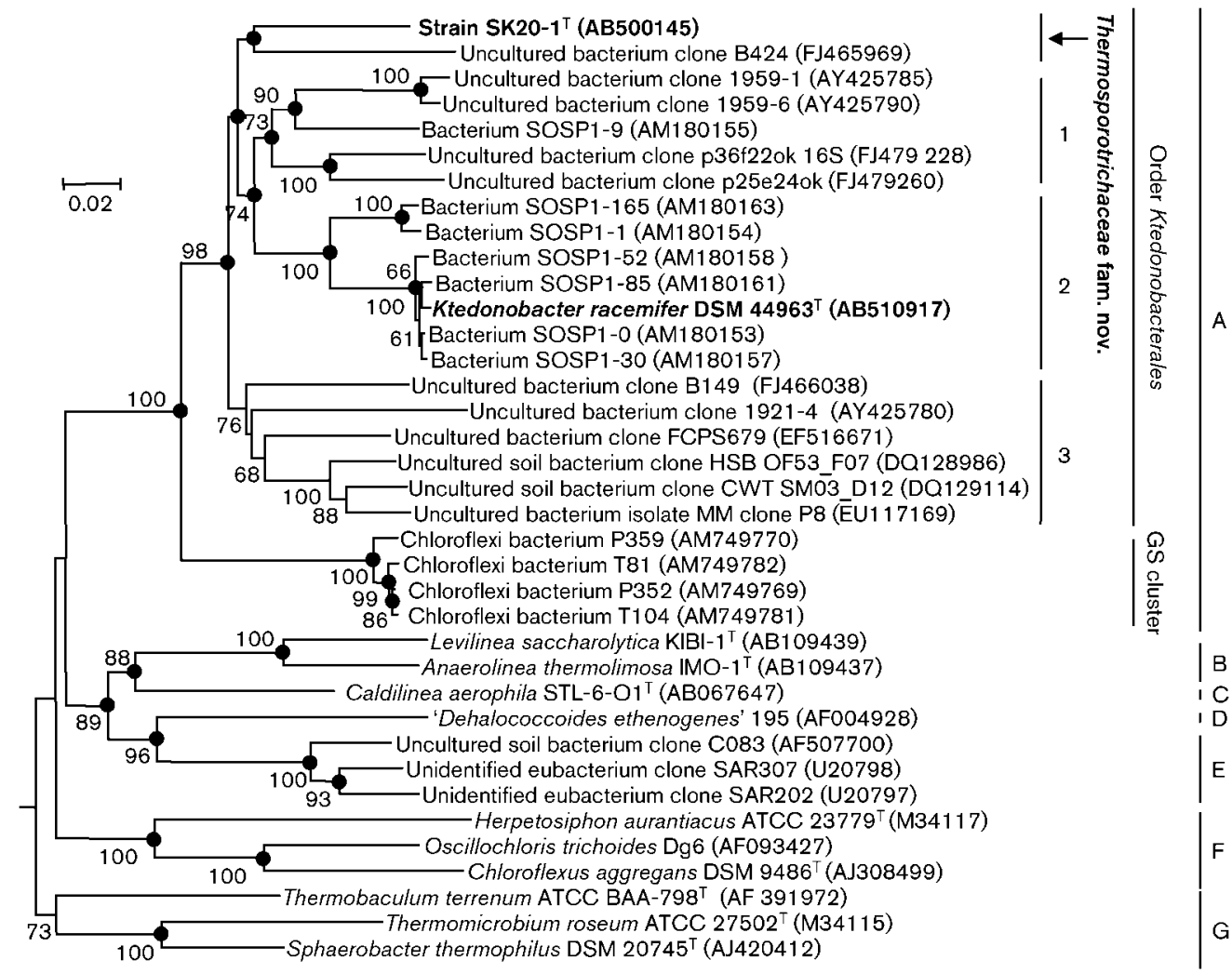

Fig. 3. Neighbour-joining tree based on 1180 aligned positions of the $16 \mathrm{~S}$ rRNA gene showing the position of strain SK20-1 ${ }^{\top}$ and $K$. racemifer DSM $44963^{\top}$ among members of the phylum Chloroflexi. The sequences of Aquifex pyrophilus Kol5a ${ }^{\top}$ and Thermotoga maritima $\mathrm{MSB}^{\top}{ }^{\top}$ were used as an outgroup (not shown). Numbers at nodes are bootstrap percentages based on 1000 replicated datasets; only values greater than $60 \%$ are shown. Bar, $2 \%$ sequence dissimilarity. Closed circles indicate nodes that were recovered using neighbour-joining method (Saitou \& Nei, 1987), maximum-likelihood (Felsenstein, 1981) and maximum-parsimony (Fitch, 1971) tree-making algorithms. Classes are indicated as follows: A, Ktedonobacteria; B, Anaerolineae; C, Caldilineae; D, 'Dehalococcoidetes'; E, clone cluster; F, Chloroflexi; G, Thermomicrobia.

closely related species, $K$. racemifer. Strain $\mathrm{SK} 20-1^{\mathrm{T}}$ is thermophilic, whereas $K$. racemifer SOSP $1-21^{\mathrm{T}}$ is mesophilic. Strain $\mathrm{SK} 20-1^{\mathrm{T}}$ hydrolyses cellulose, xylan and chitin, whereas $K$. racemifer SOSP $1-21^{\mathrm{T}}$ does not. The major fatty acid of $K$. racemifer SOSP $1-21^{\mathrm{T}}$ is $\mathrm{C}_{16: 1} 2-\mathrm{OH}$ $(29.65 \%)$, while that of strain SK20-1 $^{\mathrm{T}}$ is iso-C $\mathrm{C}_{17: 0}$ $(52.79 \%)$. The maximum colony diameter of strain SK20-1 ${ }^{\mathrm{T}}$ is $5 \mathrm{~cm}$ after incubation for 7 days under optimum conditions, while that of $K$. racemifer SOSP1$21^{\mathrm{T}}$ is $3-4 \mathrm{~mm}$ after incubation for $3-4$ weeks under optimum conditions. The features that strain $\mathrm{SK} 20-1^{\mathrm{T}}$ and $K$. racemifer have in common are being Gram-stainpositive and forming branched mycelium, which are not characteristic of the phylum Chloroflexi, but rather are similar to actinomycetes. The results of morphological, physiological and chemotaxonomic investigations, together with the phylogenetic analysis, reveal that strain $\mathrm{SK} 20-1^{\mathrm{T}}$ is clearly distinguished from $K$. racemifer at the family level. Therefore, we put forward the name Thermosporotrichaceae fam. nov. in the class Ktedonobacteria. We also propose the name Thermosporothrix hazakensis gen. nov., sp. nov. to accommodate strain SK20-1 ${ }^{\mathrm{T}}$. In addition, we propose the classification of the class Ktedonobacteria in the phylum Chloroflexi.

\section{Description of Thermosporothrix gen. nov.}

Thermosporothrix (Ther'mo.spo' ro.thrix. Gr. n. therme heat; Gr. n. spora a seed and, in biology, a spore; Gr. fem. n. thrix hair; N.L. fem. n. Thermosporothrix thermophilic spore-forming hair).

Filamentous, spore-forming bacteria. Gram-stainpositive. Thermophilic, aerobic heterotrophs. Contain glutamic acid, serine, alanine and ornithine as peptidoglycan amino acids. Cell-wall sugars are rhamnose and mannose. iso- $\mathrm{C}_{17: 0}$ is the major fatty acid and MK- $9\left(\mathrm{H}_{2}\right)$ is the major menaquinone. The $\mathrm{G}+\mathrm{C}$ content of the genomic DNA of the type strain of the type species is $54.0 \mathrm{~mol} \%$. The type species is Thermosporothrix hazakensis. 


\section{Description of Thermosporothrix hazakensis sp. nov.}

Thermosporothrix hazakensis (ha.za.ken'sis. N.L. fem. adj. hazakensis pertaining to Hazaka, referring to the isolation of the type strain at Hazaka Plant Research Center, Japan).

Displays the following properties in addition to those described for the genus. Produces branched vegetative and aerial mycelium. Spores are borne in a cluster. The nonmotile spores are fig-like in shape and are 1.0-2.0 $\mu \mathrm{m}$ long and $0.7-1.0 \mu \mathrm{m}$ wide. Growth occurs at $31-58{ }^{\circ} \mathrm{C}$ (optimum $50{ }^{\circ} \mathrm{C}$ ) and $\mathrm{pH}$ 5.4-8.7 (optimum pH 7.0). Spore cells are covered with a membrane and surrounded by thick cell walls. Does not require $\mathrm{NaCl}$; growth is inhibited completely by $3 \% \mathrm{NaCl}$. Casein, cellulose, xylan and chitin are hydrolysed, while starch and gelatin are not. Catalasepositive. D-Xylose, D-glucose, sucrose, L-rhamnose, inositol and mannitol are utilized as sole carbon sources.

The type strain is SK20-1 ${ }^{\mathrm{T}}\left(=\mathrm{JCM} 16142^{\mathrm{T}}=\right.$ ATCC BAA$1881^{\mathrm{T}}$ ), isolated from compost.

\section{Description of Thermosporotrichaceae fam. nov.}

Thermosporotrichaceae (Ther'mo.spo'ro.tri.cha'ce.ae. N.L. fem. n. Thermosporothrix -trichos type genus of the family; L. suff. -aceae ending to denote a family; N.L. fem. pl. n. Thermosporotrichaceae the family of the genus Thermosporothrix).

The description is the same as for the genus Thermosporothrix. The family is a member of the order Ktedonobacterales. The type genus is Thermosporothrix.

\section{Emended description of the class Ktedonobacteria Cavaletti et al. 2007}

On the basis of comparative 16S rRNA gene sequence analysis, the class Ktedonobacteria belongs to the phylum Chloroflexi. The class contains the order Ktedonobacterales.

\section{Acknowledgements}

Parts of this work were supported by the Center for Integrated Nanotechnology Support at Tohoku University and by the Nanotechnology Network Project of the Ministry of Education, Culture, Sports, Science, and Technology (MEXT) of the Japanese Government. We thank Mrs Keiko Furihata and Dr Midori Kurahashi (Inst. Mol. Cell. Biosci., Univ. Tokyo) and Dr Yukiyo Fukunaga (NITE Biological Resource Center; NBRC, National Institute of Technology and Evaluation; NITE) for technical guidance and suggestions and thank Eiji Aoyagi (Institute for Materials Research, Tohoku University) for technical guidance with SEM. We acknowledge Dr Jean Euzéby for support in the Latin etymology of the new family, genus and species names.

\section{References}

Bhothipaksa, K. \& Busta, F. F. (1978). Osmotically induced increase in thermal resistance of heat-sensitive, dipicolinic acid-less spores of Bacillus cereus Ht-8. Appl Environ Microbiol 35, 800-808.
Cavaletti, L., Monciardini, P., Bamonte, R., Schumann, P., Rohde, M., Sosio, M. \& Donadio, S. (2006). New lineage of filamentous, sporeforming, gram-positive bacteria from soil. Appl Environ Microbiol 72, 4360-4369.

Felsenstein, J. (1981). Evolutionary trees from DNA sequences: a maximum likelihood approach. J Mol Evol 17, 368-376.

Felsenstein, J. (1985). Confidence limits on phylogenies: an approach using the bootstrap. Evolution 39, 783-791.

Fitch, W. M. (1971). Toward defining the course of evolution: minimum change for a specific tree topology. Syst Zool 20, 406-416.

Garrity, G. M. \& Holt, J. G. (2001). Phylum BVI. Chloroflexi phy. nov. In Bergey's Manual of Systematic Bacteriology, 2nd edn, vol. 1, p. 427. Edited by D. R. Boone, R. W. Castenholz \& G. M. Garrity. New York: Springer.

Guindon, S. \& Gascuel, O. (2003). A simple, fast, and accurate algorithm to estimate large phylogenies by maximum likelihood. Syst Biol 52, 696-704.

Hall, T. A. (1999). BioEdit: a user-friendly biological sequence alignment editor and analysis program for Windows 95/98/NT. Nucleic Acids Symp Ser 41, 95-98.

Harper, J. J. \& Davis, G. H. G. (1979). Two-dimensional thin-layer chromatography for amino acid analysis of bacterial cell walls. Int $J$ Syst Bacteriol 29, 56-58.

Hugenholtz, P. \& Stackebrandt, E. (2004). Reclassification of Sphaerobacter thermophilus from the subclass Sphaerobacteridae in the phylum Actinobacteria to the class Thermomicrobia (emended description) in the phylum Chloroflexi (emended description). Int $J$ Syst Evol Microbiol 54, 2049-2051.

Janssen, F. W., Lund, A. J. \& Anderson, L. F. (1958). Colorimetric assay for dipicolinic acid in bacterial spores. Science 127, 26-27.

Kimura, M. (1980). A simple method for estimating evolutionary rates of base substitutions through comparative studies of nucleotide sequences. J Mol Evol 16, 111-120.

Lin, Y.-C., Uemori, K., de Briel, D. A., Arunpairojana, V. \& Yokota, A. (2004). Zimmermannella helvola gen. nov., sp. nov., Zimmermannella alba sp. nov., Zimmermannella bifida sp. nov., Zimmermannella faecalis sp. nov. and Leucobacter albus sp. nov., novel members of the family Microbacteriaceae. Int J Syst Evol Microbiol 54, 1669-1676.

Marmur, J. (1961). A procedure for the isolation of deoxyribonucleic acid from microorganisms. J Mol Biol 3, 208-218.

Morris, R. M., Rappé, M. S., Urbach, E., Connon, S. A. \& Giovannoni, S. J. (2004). Prevalence of the Chloroflexi-related SAR202 bacterioplankton cluster throughout the mesopelagic zone and deep ocean. Appl Environ Microbiol 70, 2836-2842.

Saitou, N. \& Nei, M. (1987). The neighbor-joining method: a new method for reconstructing phylogenetic trees. Mol Biol Evol 4, 406425.

Schleifer, K. H. \& Kandler, O. (1972). Peptidoglycan types of bacterial cell walls and their taxonomic implications. Bacteriol Rev 36, 407-477.

Shirling, E. B. \& Gottlieb, D. (1966). Methods for characterization of Streptomyces species. Int J Syst Bacteriol 16, 313-340.

Smibert, R. M. \& Krieg, N. R. (1994). Phenotypic characterization. In Methods for General and Molecular Bacteriology, pp. 607-654. Edited by P. Gerhardt, R. G. E. Murray, W. A. Wood \& N. R. Krieg. Washington, DC: American Society for Microbiology.

Stamatakis, A. (2006). RAxML-VI-HPC: maximum likelihood-based phylogenetic analyses with thousands of taxa and mixed models. Bioinformatics 22, 2688-2690.

Stott, M. B., Crowe, M. A., Mountain, B. W., Smirnova, A. V., Hou, S., Alam, M. \& Dunfield, P. F. (2008). Isolation of novel bacteria, 
including a candidate division, from geothermal soils in New Zealand. Environ Microbiol 10, 2030-2041.

Tamaoka, J. \& Komagata, K. (1984). Determination of DNA base composition by reversed-phase high-performance liquid chromatography. FEMS Microbiol Lett 25, 125-128.

Tamura, K., Dudley, J., Nei, M. \& Kumar, S. (2007). MEGA4: molecular evolutionary genetics analysis (MEGA) software version 4.0. Mol Biol Evol 24, 1596-1599.

Thompson, J. D., Higgins, D. G. \& Gibson, T. J. (1994). CLUSTAL W: improving the sensitivity of progressive multiple sequence alignment through sequence weighting, position-specific gap penalties and weight matrix choice. Nucleic Acids Res 22, 4673-4680.

Tindall, B. J. (1990a). A comparative study of the lipid composition of Halobacterium saccharovorum from various sources. Syst Appl Microbiol 13, 128-130.

Tindall, B. J. (1990b). Lipid composition of Halobacterium lacusprofundi. FEMS Microbiol Lett 66, 199-202.
Yabe, S., Kato, A., Hazaka, M. \& Yokota, A. (2009). Thermaerobacter composti sp. nov., a novel extremely thermophilic bacterium isolated from compost. J Gen Appl Microbiol 55, 323-328.

Yamada, T., Sekiguchi, Y., Hanada, S., Imachi, H., Ohashi, A., Harada, H. \& Kamagata, Y. (2006). Anaerolinea thermolimosa sp. nov., Levilinea saccharolytica gen. nov., sp. nov. and Leptolinea tardivitalis gen. nov., sp. nov., novel filamentous anaerobes, and description of the new classes Anaerolineae classis nov. and Caldilineae classis nov. in the bacterial phylum Chloroflexi. Int $J$ Syst Evol Microbiol 56, 1331-1340.

Yarza, P., Richter, M., Peplies, J., Euzéby, J., Amann, R., Schleifer, K. H., Ludwig, W., Glöckner, F. O. \& Rosselló-Móra, R. (2008). The All-Species Living Tree project: a $16 \mathrm{~S}$ rRNA-based phylogenetic tree of all sequenced type strains. Syst Appl Microbiol 31, 241-250.

Yokota, A., Tamura, T., Nishii, T. \& Hasegawa, T. (1993). Kineococcus aurantiacus gen. nov., sp. nov., a new aerobic Gram-positive, motile coccus with meso-diaminopimelic acid and arabinogalactan in the cell wall. Int J Syst Bacteriol 43, 52-57. 